\title{
Factors influencing sexual functions in Turkish female patients with migraine
}

\author{
Migrenli Türk kadın hastalarda cinsel işlevleri etkileyen faktörler
}

\author{
Devrimsel Harika ERTEM, 1 Şevin AYAN SAATÇioĞLU, ${ }^{2}$ Ayhan BINGÖL, ${ }^{2}$ Özlem MERCAN, ${ }^{2}$ \\ Gökçen ERDOĞAN, ${ }^{3}$ Serdar KOKAR, ${ }^{2}$ Hanife SAĞLAM, ${ }^{2}$ Derya ULUDÜZ ${ }^{2}$
}

\begin{abstract}
Summary
Objectives: Recent studies have shown a more frequent occurrence of sexual dysfunction in patients with headache. The aim of this study was to assess the effects of demographic and clinical characteristics and psychiatric symptoms on sexual dysfunction in Turkish female patients with migraine.

Methods: In all, 18 sexually active patients with episodic migraine (EM), 12 patients with chronic migraine (CM), and 22 healthy controls of similar age were enrolled in the study. A numeric rating scale was administered to assess pain intensity. The psychiatric symptoms and sexual function of all of the participants were evaluated using the Beck depression and anxiety scales and the Golombok-Rust Inventory of Sexual Satisfaction (GRISS).

Results: The mean GRISS subscale scores did not differ significantly between the migraine groups and the control group (all $p$ values $<0.05$ ). A positive correlation was found between the duration of headache and GRISS subscales of noncommunication, dissatisfaction, vaginismus, and anorgasmia in EM patients. In addition, there was a negative correlation with the infrequency and avoidance subscales. No correlation was detected between the GRISS subscale scores and the demographic and clinical characteristics of the patients with CM, with the exception of the level of education. Higher pain intensity scores and the presence of anxiety or depression among the EM and CM patients significantly affected all of the subscale scores of the sexual function inventory.

Conclusion: Although there was no relationship between migraine chronicity and sexual dysfunction, our data indicated that patient demographic characteristics, greater pain severity, and comorbidities of depression or anxiety were associated with greater sexual dysfunction among patients with EM and CM.
\end{abstract}

Keywords: Anxiety; depression; female; migraine; sexual function.

\section{Özet}

Amaç: Cinsel işlev bozukluğunun kronik ağrılı olgularda sık görülmesi, ağrının cinsel işlevler üzerindeki etkisine dikkat çekmektedir. Bu çalışmada epizodik ve kronik migrenli kadın olgularda baş ağrısının cinsel işlev bozukluklarına etkilerinin araştırılması amaçlanmıştır.

Gereç ve Yöntem: Çalışmamıza 18 yaş-50 yaş (ortalama yaş $32 \pm 4.24$ yıl) arasında doğurganlık döneminde 30 epizodik ve kronik migren baş ağrısı olgusu ve 22 sağlıklı kontrol dahil edildi. Olgularda demografik özellikler kaydedilerek, ağrı şiddetini belirlemek için sayısal değerlendirme ölçeği kullanıldı. Beck Depresyon ve Anksiyete Ölçekleri ve Golombok-Rust Cinsel Doyum Ölçeği (GRCDÖ) tüm migren olguları ve kontrol grubunda uygulandı.

Bulgular: Migren grupları ve kontrol grubunun GRCDÖ alt ölçek puanları arasında anlamlı fark saptanmadı. Epizodik migren grubunda yaş ve baş ağrısı süresi GRCDÖ alt ölçek puanları arasında pozitif korelasyon; öğrenim durumuyla negatif korelasyon göstermekteydi. Kronik migren grubunda öğrenim durumu ve ağrı şiddeti GRCDÖ alt ölçek puanları arasında negatif korelasyon saptandı. Ağrı şiddetinde artma, anksiyete ve depresyon varlığı, her iki migren grubunda cinsel işlevlerin tüm alt boyutlarını anlamlı olarak etkilemekteydi.

Sonuç: Çalışmamızın sonuçlarına göre migren olgularında kronikleşme ile cinsel işlev bozuklukları arasında ilişki saptanmadı ancak depresyon ve anksiyetenin eşlik ettiği kronik ve epizodik migrenli olgular sıklık, doyum, kaçınma,dokunma, vajinismus ve anorgazmi gibi cinsel işlev bozukluklarında sağlıklı bireylere göre anlamlı olarak daha fazla sorun yaşamaktalardır.

Anahtar sözcükler: Anksiyete; depresyon; kadın; cinsel işlev; migren.

'Department of Neurology, Şişli Hamidiye Etfal Training and Research Hospital, İstanbul, Turkey

${ }^{2}$ Department of Neurology, İstanbul University Cerrahpaşa- Cerrahpaşa Faculty of Medicine, İstanbul, Turkey

${ }^{3}$ Department of Obstetrics and Gynecology, Near East University, İstanbul, Turkey

Submitted (Başvuru tarihi) 17.10.2019 Accepted after revision (Düzeltme sonrası kabul tarihi) 23.03.2020 Available online date (Online yayımlanma tarihi) 06.08.2020

Correspondence: Dr. Devrimsel Harika Ertem. Şişli Hamidiye Etfal Eğitim ve Araşstrma Hastanesi, Nöroloji Kliniği, İstanbul, Turkey.

Phone: +90 - 212 - 5709144 e-mail: hkaozhan@gmail.com

(- 2020 Turkish Society of Algology 


\section{Introduction}

Sexual dysfunction is defined as a decrease in objective performance due to a negative impact on personal pleasure and/or sexual desire. ${ }^{[1]}$ Adverse effects of sexual dysfunction and its negative effects on quality of life have been reported in patients with chronic pain. ${ }^{[2]}$ Psychiatric, neurological, vascular diseases, and some drugs can cause sexual dysfunctions. ${ }^{[3]}$ Although the prevalence of migraine headache is common among women and the effects of chronic pain on quality of life and psychosocial functioning are well known from menarche to menopause, there are limited number of studies evaluating the sexual function among these patients. ${ }^{[4]}$

Psychiatric comorbid conditions such as depression and anxiety are common in patients with migraine. ${ }^{[5-7]}$ Depression and anxiety can also lead to sexual dysfunction. ${ }^{[8,9]}$ Evaluation of the effect of comorbid psychiatric conditions on sexual dysfunction in migraine cases may be an important step in the management of migraine type headaches. In addition, in migraine headache cases, there may be sexual dysfunction independently associated with psychiatric problems in parallel with the frequency and severity of pain. Even though there are some studies reporting sexual dysfunction of migraine cases, the effect of chronicity of migraine on sexual functions has not been adequately explored. ${ }^{[10,11]}$ The aim of this study was to assess sexual dysfunction in female patients with episodic and chronic migraine and to evaluate the influencing factors on sexual dysfunction.

\section{Material and Methods}

This cross-sectional, clinic-based study was approved by the ethics committee of the participating university and carried out in accordance with the Declaration of Helsinki. Written and verbal informed consents were obtained from the participants. Sexually active episodic $(n=12)$ and chronic $(n=18)$ female migraineurs aged 18-50 years who have been followed in headache outpatient unit were recruited prospectively. The diagnosis of headache was made according to their neurological examination, cranial magnetic resonance imaging (MRI) findings, and all diagnoses were based on The International Classification of Headache Disorders, 2013, ICHD-3 beta version. The control group consisted of 22 age - matched and sexually active healthy female volunteers. Episodic and chronic migraine patients without prophylactic treatment more than 3 months or medication overuse headache were included in the study. Patients under antipsychotic, antidepressant or other medications that may affect the sexual functions for the last 3 months or patients with a history of comorbid secondary headache and those with a neurological disorder other than headache namely psychiatric disorders, cardiovascular disease, endocrine disorders, urogynecologic diseases, alcohol and substance abuse, pregnant, lactating and postmenopausal cases were excluded.

Headache characteristics (pain frequency, severity, duration) and accompanying symptoms were recorded. Numerical rating scale (NRS, 1 to 10) was used to determine the severity of pain. A 21-item Beck Depression Inventory was used to determine the presence and severity of depression. In addition to emotional symptoms such as despair and guilt, physical symptoms such as fatigue and weight loss are also questioned. The Turkish validity and reliability study of the Beck Depression Inventory was performed by Hisli in 1989 and found it suitable for use in Turkish society. ${ }^{[12]}$ Beck Anxiety Inventory was used to determine the presence of anxiety. Beck Anxiety Inventory was developed by Beck et al. (1988) and used to determine the frequency of anxiety symptoms experienced by individuals. Thirteen items assess physiological symptoms, 5 items explain the direction of grip, and 3 items represent both somatic and grip symptoms. The reliability and validity in Turkey (1998) were made by Ulusoy et al. ${ }^{[13]}$ Sexual function was assessed by using Golombok-Rust Sexual Satisfaction Scale (GRISS) questionnaire. The GRISS has 28 items and is used for assessing the existence and severity of sexual problems. The validity and reliability of Turkish version of GRISS were conducted by Tuğrul et al. ${ }^{[14]}$ Questions are answered on a five-point Likert type scale from 'always', through 'usually', 'sometimes', and 'hardly ever', to 'never'. Re-sponses are summed up to give a total raw score range $28-140$, with high scores indicating greater problems. GRISS provides information on the quality of sexual functions of the participant by questioning the frequency of sexual intercourse, peer communication, sexual satisfaction, avoidance, frequency of touch, presence of vaginismus and anorgasmia.

Statistical Package for Social Sciences (SPSS) 23.0 package program was used for statistical evaluation. 
Table 1. Demographic and clinical characteristics of patient and control groups

\begin{tabular}{lcccc}
\hline & Chronic migraine & Episodic migraine & Control group & p \\
\hline Number of patients & 18 & 12 & 22 & - \\
Age & $42 \pm 7.1$ & $36.3 \pm 8.4$ & $36.2 \pm 8.9$ & $0.434^{*}$ \\
Marital Status & Single: 12 & & & \\
Married: 6 & Single: 8 & & \\
Married: 4 & Single: 13 & & \\
Married: 9 & $0.551^{* *}$ & & \\
Level of education (n) & Primary: 10 & & \\
Secondary/university: 8 & Primary: 7 & & \\
Secondary/university: 5 & Primary: 10 & & \\
Secondary/university: 12 & $0.229^{* *}$ & & & \\
Level of income (n) & None:6 & & & \\
Min.wage or above: 12 & None:4 & & & \\
Min.wage or above: 8 & None:7 & & & \\
Min.wage or above: 15 & $0.991^{* *}$ & & & \\
Duration of headache (year) & $7.04 \pm 5.29$ & $6.84 \pm 3.78$ & \\
Mean numeric ratig scale & $7.7 \pm 2.3$ & $6.8 \pm 2.1$ & \\
\hline
\end{tabular}

*: Kruskal Wallis test results; **: Chi-square test results; ***: Mann Whitney U test results.

Table 2. Participants' mean sexual function scores for each GRISS subscale

\section{GRISS subscale}

Chronic migraine

Infrequency

Non-communication

Dissatisfaction

Avoidance

Nonsensuality

Vaginismus

Anorgasmia

Patients and control groups

$\begin{array}{lllll}5.11 \pm 0.46 & 3.90 \pm 0.59 & 3.82 \pm 3.76 & 5.44 & 0.066 \\ 4.44 \pm 0.58 & 4.30 \pm 0.87 & 3.32 \pm 0.55 & 2.12 & 0.347 \\ 4.78 \pm 0.83 & 4.50 \pm 1.10 & 3.38 \pm 0.78 & 1.36 & 0.507 \\ 4.33 \pm 0.93 & 2.90 \pm 0.72 & 3.45 \pm 0.72 & 0.93 & 0.628 \\ 4.83 \pm 0.86 & 5.40 \pm 1.55 & 3.68 \pm 0.78 & 1.38 & 0.503 \\ 6.00 \pm 0.90 & 6.40 \pm 1.11 & 4.45 \pm 0.78 & 3.24 & 0.198 \\ 6.44 \pm 1.14 & 6.20 \pm 1.30 & 4.91 \pm 0.82 & 1.24 & 0.539\end{array}$

*: Kruskal Wallis test results; GRISS: Golombok Rust Inventory of Sexual Satisfaction Scale.

Descriptive statistics were shown as mean \pm standard deviation for continuous variables. Kruskal-Wallis test was used for comparison of multiple groups. Mann-Whitney $U$ test was used for comparison of two groups. The relationship between the variables was evaluated by Spearman Correlation Analysis. The level of significance was accepted as $p<0.05$.

\section{Results}

Thirty female patients were enrolled, of which 12 were episodic migraine (EM) and 18 had chronic migraine $(C M)$. The mean age of patients was $32 \pm 4.24$ (range 18 to 50). We compared patients with EM, patients with $\mathrm{CM}$, and 22 age - matched and sexually active healthy controls in terms of age, marital status, level of education, and income. No significant differences among the three groups in terms of those parameters were detected (all $p$ values $>0.05$ ). There was no difference between the mean NRS scores of patients groups and onset of headache ( $p>0.05)$. Details of demographic and clinical features of participants were given in Table 1.

The mean Beck Depression Inventory (BDI) scores of the CM patients was $14.4 \pm 10.5$; EM patients' scores 


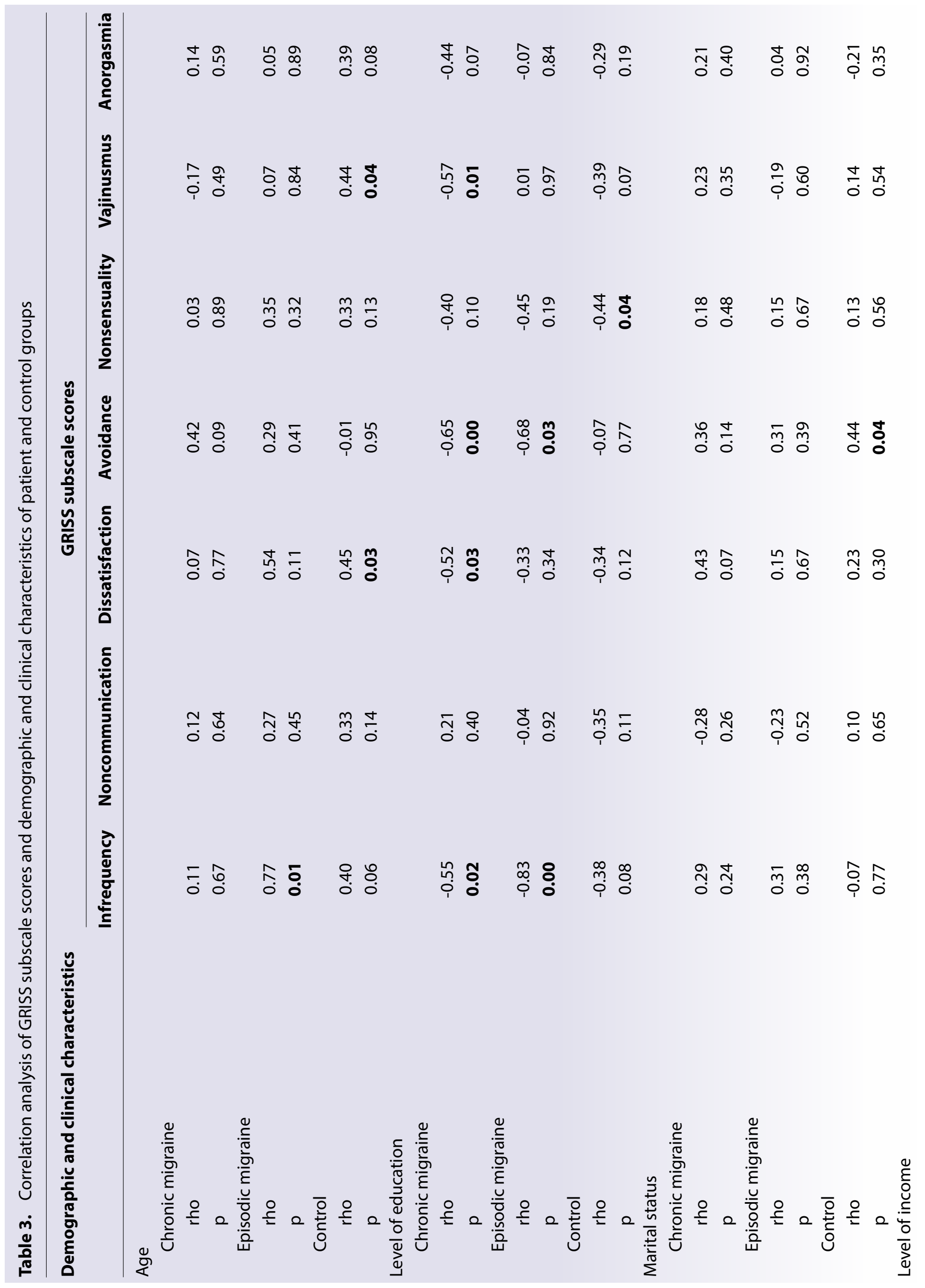




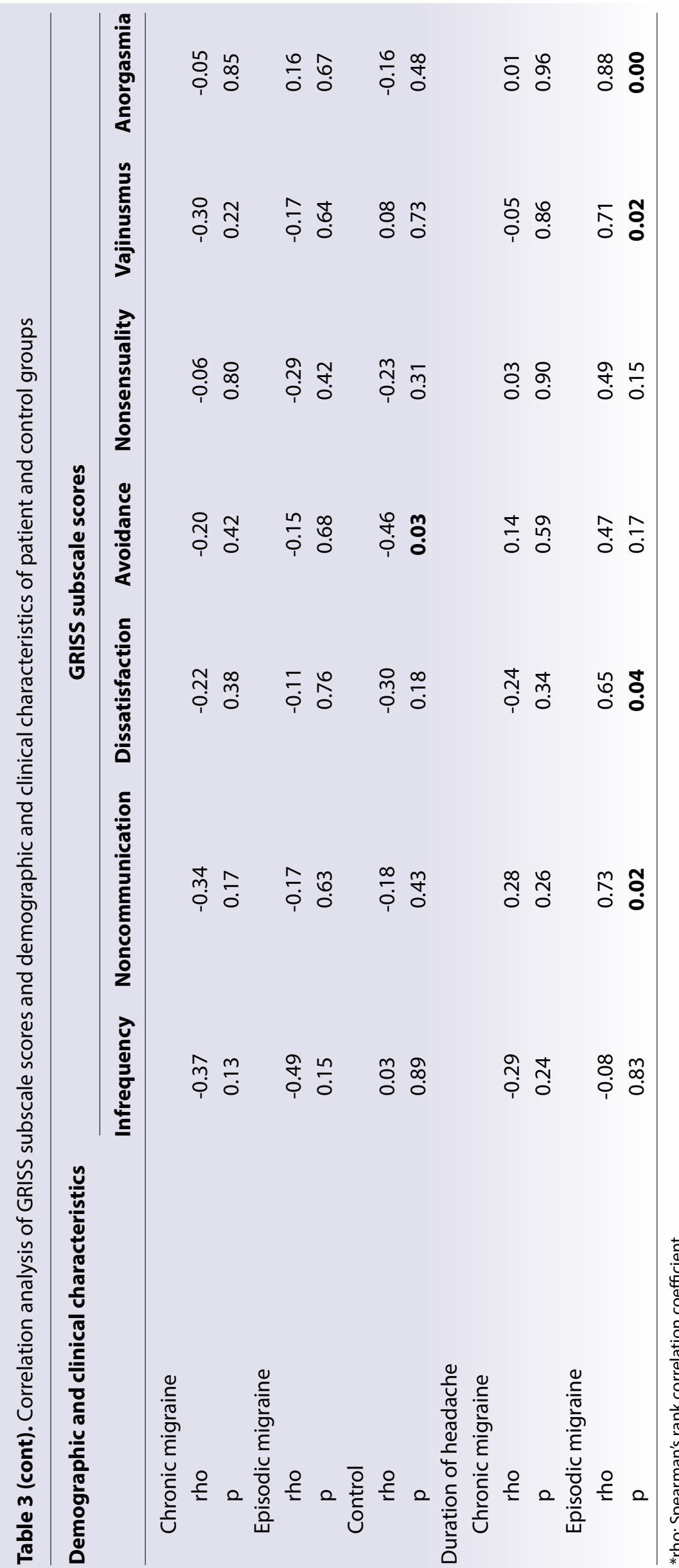

were $11.7 \pm 10.7$, and $6.9 \pm 5.7$ in the control group ( $p>0.05$ ). The mean Beck Anxiety Inventory (BAI) scores of the CM patients was 19.8 \pm 12.3 ; EM patients were $19.9 \pm 14.7$, and $8.9 \pm 8.6$ in the control group ( $p>0.05)$. The mean anxiety scores of the migraine groups was significantly higher than the control group $(p=0.03)$.

The overall GRISS score and the score for each subscale did not show significant difference in migraine groups and controls $(p>0.05)$. Comparison of scores of sexual dysfunction in studied patients according to GRISS questionnaire were demonstrated in Table 2 . The correlation between demographic and clinical data of the participants and the GRISS subscale scores; infrequency, non-communication, dissatisfaction, avoidance, nonsensuality, vaginismus, and anorgasmia were shown in Table 3.

Age had no significant effect on GRISS subgroup scores except infrequency scores of episodic migraines on which getting older had a growing effect $(p=0.01 ; r=0.77)$. In patients with chronic migrane; education level showed negative correlation with 4 subscale scores, such as infrequency $(p=0.02$; $r=-0.55)$, dissatisfaction $(p=0.03 ; r=-$ $0.52)$, avoidance $(p=0.00 ; r=-0.65)$ and vaginismus $(p=0.01 ; r=-0.57)$; where as in patients with episodic migrane it showed negative correlation with only 2 subscale scores, namely infrequency $(p=0.00 ; r=-0.83)$ and avoidance (0.03; $r=-0.68)$. Despite having no significant relation with subscale scores of chronic migrane group, onset of headache had positive correlation with 4 out of 6 subscale scores in episodic migrane group, such as non-communication $(p=0.02$; $r=0.73)$, dissatisfaction $(p=0.04 ; r=0.65)$, vaginismus $(p=0.02 ; r=0.71)$ ve anorgasmia $(p=0.00 ; r=0.88)$. There were no significant relation between subscale scores and level of income. 
The correlation between mean GRISS subscale scores and Beck Depression and Anxiety Invantory scores and NRS scores for each groups was demonstrated in Table 4. Depression scores had a positive correlation with infrequency, dissatisfaction, avoidance, nonsensuality and vaginismus $(p=0.00$; between $r=0.61$ 0.87 ) in chronic migrane group, and with dissatisfaction ( $p=0.01 ; r=0.75)$, avoidance $(p=0.00 ; r=0.87)$, nonsensuality $(p=0.01 ; r=0.78)$ in episodic migrane group. Anxiety scores also showed positive correlation with subscale scores, such as avoidance $(p=0.01$; $r=0.61)$, vaginismus ( $p=0.02 ; r=0.54)$ and anorgasmia $(p=0.02 ; r=0.55)$ in chronic migrane group, and with dissatisfaction ( $p=0.01 ; r=0.75)$, avoidance $(p=0.00$; $r=0.87)$, nonsensuality $(p=0.01 ; r=0.78)$ in episodic migrane group. Despite the fact that avoidance $(p=0.02$; $r=0.55)$ and anorgasmia $(p=0.02 ; r=0.53)$ were affected by NSR scores in chronic migrane group, no significant relation found between NRS scores and all GRISS subscales in episodic migrane group.

\section{Discussion}

This study was conducted to evaluate the existence and types of sexual dysfunctions in women with episodic and chronic migraine, determine the effects of concomitant depression and anxiety on sexual functions and to investigate its association with patients' characteristics. A lower level of education and higher age and duration of headache were the major characteristics of patients that affected all sexual functions. Furthermore, higher pain severity scores were related to higher total GRISS scores. Our findings showed that the chronicity of migraine was not related to sexual dysfunction. However, higher anxiety and depression scores appeared to be associated with decreased sexual functioning in both migraine groups.

In a study by Aksoy et al., ${ }^{[3]}$ in which sexual functions, especially erectile function, were evaluated in male patients with migraine and tension type headache, it was reported that sexual functions were significantly affected in both groups compared to the healthy control group, but they did not find any difference between the headache groups. The authors did not find a relation of sexual dysfunction with Beck depression scores in these primary headache patients. They stated that there should be other heterogeneous factors causing the sexual dysfunctions in patients with primary headaches other than psychiatric symptoms. Our study, which showed the increase in pain severity affected the sexual functions in both episodic and chronic migraine patient groups, supports the opinion of Aksoy et al.

Bestepe et al. ${ }^{[10]}$ compared the features of sexual functions between patients with tension type headaches, migraine and healthy controls and found no statistically significant difference in headache frequency, severity of pain, and duration between patients with migraine and tension type headache. Our research differs from this study in some features. In the current study, the effects of chronicity of migraine on sexual functions were assessed. Unlike their study, demographic and clinical variables such as age, level of education and duration of headache have been shown to have negative impacts on sexual functions in our cases. Similar to our findings, Maizels et al. ${ }^{[15]}$ reported that they did not find an association between frequency of headache and sexual dysfunction in migraineurs. Eraslan et al. ${ }^{[11]}$ reported that sexual dysfunction was not related to migraine related disability, frequency of headache attacks, pain severity or anxiety. The authors suggested that the most important factor that predicted sexual function was depression. Our findings implicated that depression affected sexual satisfaction, avoidance, frequency of touch in patients with episodic migraine and all sexual functions in patients with chronic migraine. However, anxiety has been found to be related to sexual dysfunction in our patient settings. In this study, comparison of the patients with episodic and chronic migraine may have resulted in different outcomes from their study. According to our results, it can be concluded that comorbid depression and anxiety symptoms may contribute to worsening of sexual functions in patients with episodic and chronic migraine even though underlying pain frequency is different.

In a study conducted by Abdollahi, the prevalence of sexual dysfunction in women with migraine was reported to be significantly more frequent than the general population in Iran. ${ }^{[16]}$ Moreover, desire and arousal disorder were found to be the most common types of sexual dysfunction among Iranian migraineurs. However, dissimilar to our data, the researchers found an association between sexual dysfunction and headache frequency. According to 


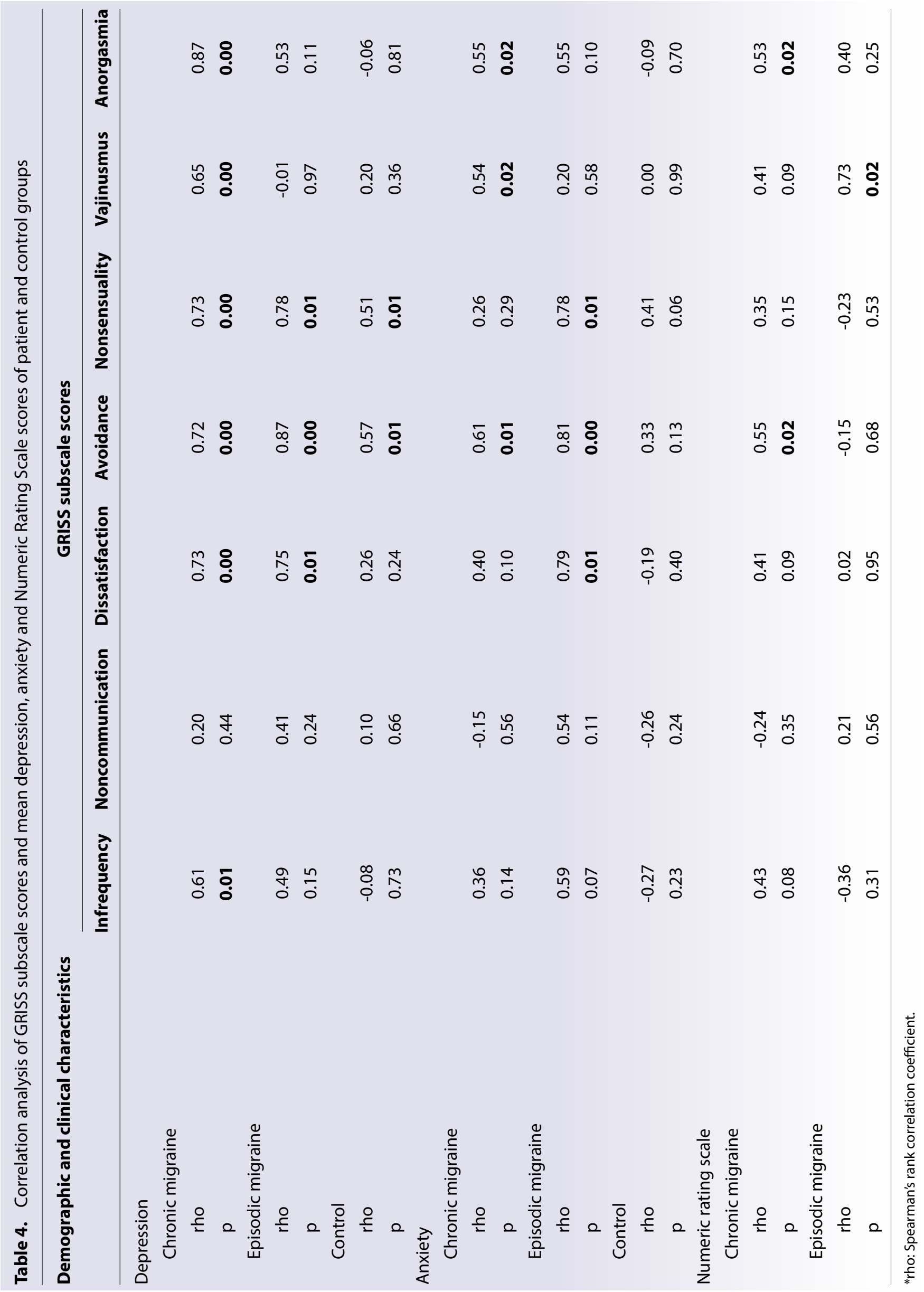


our results, different types of sexual functions got affected among episodic and chronic migraineurs regardless of the chronicity of migraine. This can be explained by the differences in cultural and psychosocial factors of migraine patients.

Sexual dysfunction and related problems may cause psychosocial problems such as low self-esteem, social withdrawal, isolation, divorce, and serious decrease in quality of life for the patient and his/her partner. ${ }^{[17,18]}$ Fear of onset of pain during sexual activity may also have a negative effect on sexual functions. ${ }^{[2]}$ Bestepe et al. reported a patient with tension type headache during the sexual intercourse. ${ }^{[10]}$ Özcan et al. ${ }^{[19]}$ presented a case of primary headache associated with sexual activity. Furthermore, it is reported that migraine type headaches might be aggravated by sexual abuse. ${ }^{[20]}$ In our series, none of the participants reported headaches related to sexual activity.

We acknowledge some limitations in this study. These include the small sample size and using self report inventories. Nevertheless, the strength of our study includes that we compared our results with healthy subjects. Besides this, we evaluated the psychiatric symtoms and sexual functions using an objective and validated inventory in our study and found a relationship between migraine and depression and axiety. The fact that we are an Islamic country may have brought differences in the perception of sexuality according to western countries. The GRISS, which we use for evaluating sexual functions, is a highly detailed scale and evaluates many aspects of sexual functions. The scores of the scale were interpreted by experienced pscycologists who were blinded to the clinical data. Including chronic migraine patients without migraine prophylactics prevented the heterogeneity caused by the medication known to have an effect on sexual function.

\section{Conclusion}

Conforming to the results of our research, it can be concluded that there is an association between sexual dysfunction, psychiatric comorbidity, and pain severity in patients with episodic and chronic migraine. There are not enough studies evaluating the chronicity of migraine and sexual dysfunction in the current literature. Our study may be improved by assessing the effects of migraine prophylactic treat- ments and concurrent medication use, and evaluating headache patients with medication overuse in future research.

Acknowledgements: The authors wish to thank Mr Mustafa Cem Ertem for his statistical support.

Ethics Committee Approval: The Istanbul University Cerrahpaşa Clinical Research Ethics Committee granted approval for this study (date: 07.08.2018, number: 83045809-604.01.02).

Conflict-of-interest issues regarding the authorship or article: None declared.

Peer-rewiew: Externally peer-reviewed.

\section{References}

1. Srivastava R, Thakar R, Sultan A. Female sexual dysfunction in obstetrics and gynecology. Obstet Gynecol Surv 2008;63(8):527-37. [CrossRef]

2. Kwan KS, Roberts LJ, Swalm DM. Sexual dysfunction and chronic pain: the role of psychological variables and impact on quality of life. Eur J Pain 2005;9(6):643-52. [CrossRef]

3. Aksoy D, Solmaz V, Cevik B, Gencten Y, Erdemir F, Kurt SG. The evaluation of sexual dysfunction in male patients with migraine and tension type headache. J Headache Pain 2013;14(1):46. [CrossRef]

4. Nappi RE, Terreno E, Tassorelli C, Sances G, Allena M, Guaschino $E$, et al. Sexual function and distress in women treated for primary headaches in a tertiary university center. J Sex Med 2012;9(3):761-9. [CrossRef]

5. Buse DC, Silberstein SD, Manack AN, Papapetropoulos S, Lipton RB. Psychiatric comorbidities of episodic and chronic migraine. J Neurol 2013;260(8):1960-9. [CrossRef]

6. Sharma K, Remanan R, Singh S. Quality of life and psychiatric co morbidity in Indian migraine patients: a headache clinic sample. Neurol India 2013;61(4):355-9.[CrossRef]

7. Doksat MK. The Psychiatric aspects of headache. Turkiye Klinikleri J Int Med Sci 2005;1:50-6.

8. Hayes RD, Dennerstein L, Bennett CM, Sidat M, Gurrin LC, Fairley CK. Risk factors for female sexual dysfunction in the general population: exploring factors associated with low sexual function and sexual distress. J Sex Med 2008;5(7):1681-93. [CrossRef]

9. Burri A, Spector T, Rahman $Q$. The etiological relationship between anxiety sensitivity, sexual distress, and female sexual dysfunction is partly genetically moderated. J Sex Med 2012;9(7):1887-96. [CrossRef]

10. Bestepe E, Cabalar M, Kucukgoncu S, Calıkusu C, Ornek F, Yayla V, et al. Sexual dysfunction in women with migraine versus tension-type headaches: a comparative study. Int J Impot Res 2011;23(3):122-7. [CrossRef]

11. Eraslan D, Yalınay Dikmen $P$, Ilgaz Aydınlar E, Incesu C. The relation of sexual function to migraine-related disability, depression and anxiety in patients with migraine. J Headache Pain 2014;15(1):32. [CrossRef] 
12. Hisli N. Beck Depresyon Envanterinin Üniversite Öğrencileri için Geçerliliği ve Güvenirligi. Psikoloji Dergisi 1989;7:3-13.

13. Ulusoy M. Beck Anksiyete Envanteri: Geçerlik ve güvenirlik çalışması. Yayımlanmamış Uzmanlık Tezi. İstanbul: Bakırköy Ruh ve Sinir Hastalıkları Hastanesi, 1999.

14. Tuğrul C, Öztan N, Kabakçı E. Golombok Rust Cinsel Doyum Ölçeği'nin Standardizasyon Çalışması. Turk Psikiyatri Derg 1993;4(2):83-8.

15. Maizels $M$, Burchette R. Somatic symptoms in headache patients: the influence of headache diagnosis, frequency, and comorbidity. Headache 2004;44(10):983-93. [CrossRef]

16. Abdollahi M, Toghae M, Raisi F, Saffari E. The prevalence of female sexual dysfunction among migraine patients. Iran J
Neurol 2015;14(1):8-11.

17. Hashizume M, Yamada U, Sato A, Hayashi K, Amano $Y$, Makino $M$, et al. Stress and psychological factors before a migraine attack: a time-based analysis. Biopsychosoc Med 2008;2:14. [CrossRef]

18. Althof SE. Quality of life erectile dysfunction. Urology 2002;59(6):803-10. [CrossRef]

19. Özcan T, Yancar Demir E, İşcanlı MD. Primary headache associated with sexual activity: A case report. Agri 2017;29(2):79-81.

20. Kaleağasi H, Ozge A, Toros F, Kar H. Migraine type childhood headache aggravated by sexual abuse: case report. Agri 2009;21(2):80-2. 